\title{
ACOUSTIC MEASUREMENT ON VOWEL PRODUCTION OF ENGLISH AS A SECOND LANGUAGE BY INDONESIAN EFL LEARNERS
}

\author{
Rudha Widagsa \\ English Language Education Study Program, University of PGRI Yogyakarta \\ E-mail: widagsa@upy.ac.id \\ Ahmad Agung Yuwono Putro \\ Elementary Teacher Education Study Program, University of PGRI Yogyakarta \\ E-mail: agungyuwonoahm@gmail.com
}

\begin{abstract}
APA Citation: Widagsa, R., \& Putro, A. A. Y. (2017). Acoustic measurement on vowel production of English as a second language by Indonesian learners of English. English Review: Journal of English Education, 6(1), 71-80. DOI: 10.25134/erjee.v6i1.772.
\end{abstract}

Received: 20-08-2017

Accepted: $17-10-2017$

Published: 01-12-2017

\begin{abstract}
Indonesian is the most widely spoken language in Indonesia. More than 200 million people speak the language as a first language. However, acoustic study on Indonesian learners of English (ILE) production remains untouched. The purpose of this measurement is to examine the influence of first language (L1) on English vowels production as a second language (L2). Based on perceptual magnet hypothesis (PMH), ILE were predicted to produce close sounds to L1 English where the vowels are similar to Indonesian vowels. Acoustic analysis was conducted to measure the formant frequencies. This study involved five males of Indonesian speakers aged between 20-25 years old. The data of British English native speakers were taken from previous study by Hawkins \& Midgley (2005). The result illustrates that the first formant frequencies (F1) which correlates to the vowel hight of Indonesian Learners of English were significantly different from the corresponding frequencies of British English vowels. Surprisingly, the significant differences in second formant (F2) of ILE were only in the production of $/ \mathrm{a}, \mathrm{p}, \mathrm{o} /$ in which $/ \mathrm{a} /=p 0.002, / \mathrm{p} /=p 0,001, / \mathrm{d} /=p 0,03$. The vowel space area of ILE was slightly less spacious than the native speakers. This study is expected to shed light in English language teaching particularly as a foreign language.
\end{abstract}

Keywords: VSA, EFL, Indonesian learners, formant frequencies, acoustic

\section{INTRODUCTION}

Second language (L2) learners particularly adults would experience difficulties in learning foreign sounds due to the strong influence of their first language (L1) (Lord, 2008; Flege, 1999). The level of difficulty experienced by the learner will be directly related to the degree of linguistic difference between L1 and L2 and the length of exposure on L2 (Lado, 1957; Baker \& Trofimovich, 2005). Some phonetic features of L2 which do not exist in L1 are considered as the most influenced factor in L2 learning (McAllister, Flege, \& Piske, 2002). In general, the greater the perceived phonetic dissimilarity between an L2 sound and the closest L1 sound, the more likely it is that phonetic difference between the sounds will be discerned (Flege,
Schirru, \& Mackay, 2003). Equally, some L2 sounds which similar to L1 would be easy for L2 learners to produce and some L2 sounds which are dissimilar to L1 would be awkward for L2 learners.

Similarly, the vast difference between English and Indonesian vowel system would lead to the distinctive vowel production. Dissimilarities in features existing in both English and Indonesian would generate obstacles to learning the target language. This could be a barrier for Indonesian learners of English (ILE) who want to speak or produce native-like sounds. To put it differently, ILE are predicted to experience difficulties in producing English vowels since the Indonesian phonetic system influences their 
L2 production. The difficulties could be manifested in L2 distinctive vowels quality (Baker \& Trofimovich, 2005).

The influence of L1 on L2 vowel production could simply be recognized in formant frequency values. In most cases, formant frequencies are reliable to identify correct pronunciation and intelligibility (Peterson \& Barney, 1952). Formant frequencies have long been used by researchers to measure vowel quality due to acceptable parameters and close correlation with vowel quadrilateral or vowel space area (VSA) (Ferragne \& Pellegrino, 2010;

Hillenbrand \& Nearey, 1999). Estimation of VSA has a long history in the study of vowel identity, speaker characteristics, speech development, speaking style and sociolinguistic factors which influence vowel production (Sandoval, et al., 2013).

The relationship between first formant (F1) and the second formant (F2) reflects the acoustic quality of vocoid articulations. The first formant frequency (F1) is inversely correlated to vowel height. In the same way, the higher F1 will be, the shorter it is. In other words close vowels have lover F1 Values and open vowels have higher $\mathrm{F} 1$ values. The second formant frequency (F2), on the other hands, related to the length of the oral cavity in terms of frontness and backness of the tongue body. The lower F2 will be, the longer the front cavity; the higher F2 will be, the shorter it is. In other words, back vowels have lower $\mathrm{F} 2$ values and front vowels have higher F2 values (Ball \& Lowry, 2001, p. 67;

Ladefoged, 2011, p. 196; Lodge, 2009, p. 190199).

This current study investigates the English vowel production of Indonesian native speakers by measuring the formant frequencies ( $\mathrm{F} 1$ and $\mathrm{F} 2$ values) of English vowels. It is started by reviewing and explaining the supporting theories and the previous study. A second language theory, perceptual magnet hypothesis $(\mathrm{PMH})$ proposed by Iverson \& Kuhl (1995) is considered as the basic principal of this studies. PMH proposes that adults learning a second language would find it difficult to perceive a phonetic contrast from a new language when the sounds are close to a native language prototype (Iverson \& Kuhl, 1995). In other words, foreign language learners tend to produce approximations L2 phonemes based on L1 phonemes, they will produce L2 where there is a similar sound in L1, it simply puts that the learners would attract L2 phonemes to sample phonemes in L1.

Based on PMH due to the vast differences between Indonesian and English vowel systems, the hypothesis predicts that Indonesian learners of English would have difficulties in producing some English vowels which are not represented in their L1. To examine the production patterns of English vowels by Indonesian English language learners, we set two research questions: (1) would Indonesian learners of English show the same formant frequencies producing new vowels (/i:, æ, a:, o:, u:, $\Lambda$, 3:/)? Using PMH, it is predicted that ILE would succeed to produce some English vowels where the vowels are similar in L1, conversely, ILE would be less successful in producing some English vowels which are different from L1 and the production of the English vowels would be identical to the nearest Indonesian vowels; (2) To what extent that VSA English vowels produced by ILE are different from English-L1 VSA? Based on PMH, ILE would have different size of VSA from the corresponding VSA produced by English-L1.

There are several studies prior to this acoustic measurement represented in formant frequencies in second language acquisition. For instance, Reeder (1999) found that beginning and intermediate English learners of Spanish did not fully acquire any of the Spanish vowels. He reported that the position of a vowel in the vowel space effected learners' performance in unstressed vowels. Flege et al., (2003) examined different age of acquisition of Italian speakers in learning English. They argued that early Italian learners of English produced more formant movements. Differing from early learners, adult learners seemed to produce less movement in formant frequencies. They also noticed the different characteristics between L1 and L2. Apart from this, Hunter \& Kebede (2012) analyzed the native speakers of Farsi in 
producing British English vowels. These authors found that Farsi speakers generally produced good approximations (in terms of F1 and F2 Values) to British English vowels when there is a close similarity in Farsi vowel inventories. Conversely, speakers of Farsi were frequently confused some British English vowels due to dissimilarities. Related argument is also stated by Pillai and Delavari (2012), they said that Iranian learners of English did not contrast the vowel differences between English and Iranian in term of quality.

However, in Indonesia, the measurement of second language oral production was based on teachers' auditory judgment, furthermore, acoustic studies related to second language learning received little attention. Perwitasari, Klamer, \& Schiller (2016) investigated the formant frequencies of Javanese and Sundanese learners of English. They found that the production of English vowels was challenging for the Javanese and Sundanese EFL learners not only for similar sounds such as $(/ \mathrm{I}, \varepsilon, \mho /)$, but also for new sounds such as (/i:, æ, a:, o:, u:, $\Lambda, 3: /)$. Additionally, The Javanese and Sundanese speakers showed a smaller vowel space area than that of the native English speakers.

\section{Indonesian vowel system}

Indonesian or bahasa Indonesia is a national language and lingua franca among thousands of different native speakers of indigenous languages in Indonesia. It is generally spoken as a second language. However, the language has native speakers who speak Indonesian as a first language. Indonesian is rooted from Malay, an Austronesia language family (Poedjosoedarmo, 1996; Clynes \& Deterding, 2011). The language has only six monophthongal phonemes including /i, u, e, ə, o and a/ (Muslich 2008, p. 95). Long-short (tense-lax) forms are not found in the language. There is allophonic variation between realizations in open and closed syllables but there is no agreement on the extent to which allophonic variation takes place (Halim, 1974, p. 169).

Indonesian vowels are pronounced differently in many regions in this country. However, these differences are only in accent. To illustrate this, in South Sumatera, it is found that each of the six vowels, except /a/ and $/ \mathrm{\partial} /$, is phonetically represented by two allophonic variants; according to Dardjowidjojo (2009) allophonic variation occurs in all monophthongs except / //. Subardi in Marsono (2008, p. 37) stated that there are ten vowels due to Javanese interference. Since the speech data were taken in Yogyakarta, it should also be noted that the respondents have some knowledge of Javanese, that belongs to the Austronesian language family. It follows that some degrees of Javanese accent can be detected, see Poedjosoedarmo (1982) and Adisasmito-smith (1999). A part from this, Zanten \& Goedemans (2010) had also mention that Indonesian language which is derived from Malay has 6 distinctive vowels, the variation on pronunciation is considered as allophonic variation due to influence of regional dialects (Zanten \& Goedemans, 2010).

English, by contrast, has at least 11 vowels inventories. Vowels of English vary enormously by variety, many phoneticians have different perspective in defining the number of English vowels. Jones (1957, p. 63) mentioned that there are eight vowels in Southern English, whereas Finegan, et al. (1992, p. 40) proposed twelve vowels for Australian English. However, English has at least 11 pure vowel sounds or monophthong. The vowel comparison for both languages is illustrated as follows. 


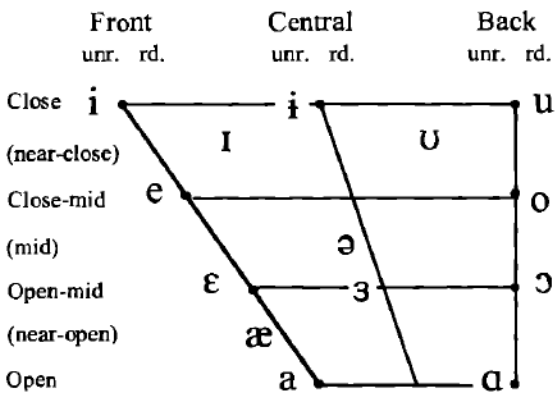

Figure 1.

English vowel chart

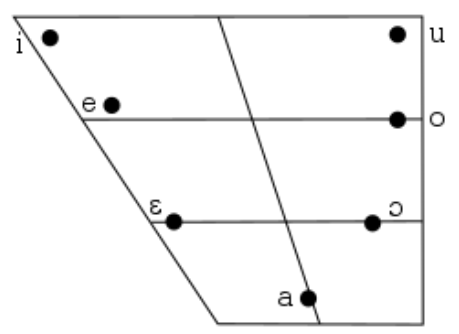

Figure 2.

Indonesian vowel chart

\section{METHOD}

This experiment involved five Indonesian speakers (all male) as the subjects of this study. The subjects were aged between 18 and 25 years at the time of data collecting. They were born in various regions in Indonesia and raised in a cross-ethnique parents which allow them to speak Indonesian as a first language. The subjects have been studying English in university for at least 3 years as the major study. When the data was taken, the
Indonesian subjects resided in Yogyakarta (a city in Java, Indonesia) and have never been to English speaking countries or travelling abroad. Meanwhile, the native speakers data used in this research were collected from Hawkins \& Midgley (2005). The subjects were native speaker of British English (BE) aged 20-25 at the time of recording. They were born in a wide range of geographical areas in order to reduce risk of a regional-specific feature being interpreted as part of a general trend.

Table 1. British F1 and F2 average (in Hertz) by Hawkins \& Midgleys (2005)

\begin{tabular}{cccccccccccc}
\hline & heed & hid & head & had & hard & hod & hoard & hood & who'd & hud & herd \\
\cline { 2 - 13 } & i: & I & e & $\boldsymbol{x}$ & a & p & o & $\boldsymbol{\sigma}$ & u & $\boldsymbol{\Lambda}$ & $\mathbf{3}$ \\
\hline F1 & 276 & 393 & 600 & 917 & 604 & 484 & 392 & 413 & 289 & 658 & 494 \\
\hline F2 & 2338 & 2174 & 1914 & 1473 & 1040 & 865 & 630 & 1285 & 1616 & 1208 & 1373 \\
\hline
\end{tabular}

Each participant was given a printed material containing a set of $11 / \mathrm{hVd} /$ words (heed, hid, head, had, hard, hod, hoard, hood, who'd, hudd, herd) in a carrier sentence. After participants received the material then they were asked to listen to it in order to get better understanding and comprehension about the words. The listening materials are taken from Oxford Advanced Learner's Dictionary. Immediately after listening section, they were instructed to pronounce the words in carrier sentences.

The recordings were made with SONY ICD PX 333 Voice Recorder and an attached headset-microphone placed at the distance of about $10 \mathrm{~cm}$ from the participants' mouth. The participants were recorded one by one in order to ease the analysis. ASUS X200MA notebook was used to analyze the recording data. This recording process took place in language laboratory of University of PGRI Yogyakarta.
Speech analysts are usually concerned mainly with the first and the second formant ( $\mathrm{F} 1$ and F2). In this study, we only measure the F1 and F2 to figure out the formant frequencies of English vowels in Hertz (Hz). The values then plotted to vowel chart/vowel quadrilateral for further analysis.

The recordings were analyzed using PRAAT 5.3.51 (Boersma \& Weenink, 2013). The software allows some features such as tracing the formant frequencies, choosing time point, and drawing waveform and spectrogram display. The formant frequencies (F1 and F2) values were traced by identifying on the formant peak of the chosen time point. The value of pitch was automatically computed through the spectrogram display. To measure a difference between the ILE vowel productions and L1 English, this research conducted statistical analysis. An independent $t$-test for the groups was applied to test whether 
frequencies and speech duration was significantly different between groups.

\section{RESULTS AND DISCUSSION}

Each vowel has a formant structure which indicates vowel height, tongue advancement and lip shape. Formants have long been known as suited parameters for describing vowel production due to its correlation with traditional alticulatory transcription of vowel. The first formant frequency (F1) is inversely related to vowel height. F1 corresponds to tongue height: close vowels have lower F1 values, and open vowels have higher $F 1$ values while F2 usually reflects the front-back position of the tongue, with front vowels having higher $\mathrm{F} 2$ values than back vowels.
https://journal.uniku.ac.id/index.php/ERJEE

Lip-rounding is indicated by a lowering of all of the formant values (Ball \& Lowry, 2001, p. 67; Ladefoged, 2011, p. 196).

There is nothing particularly new about this way of analyzing vowel sounds. The general theory of formant frequencies was stated by the great German scientist Hermann Helmholtz about one hundred fifty years ago (Ladefoged \& Johnson, 2001). Formant frequencies allow to enable visual investigation which shows the relationship between traditional articulatory descriptions and formants when it is plotted in a Bark Scale or vowel quadrilateral. The following figure is the illustration of the formant frequencies of British English vowels produced by native speakers of English.

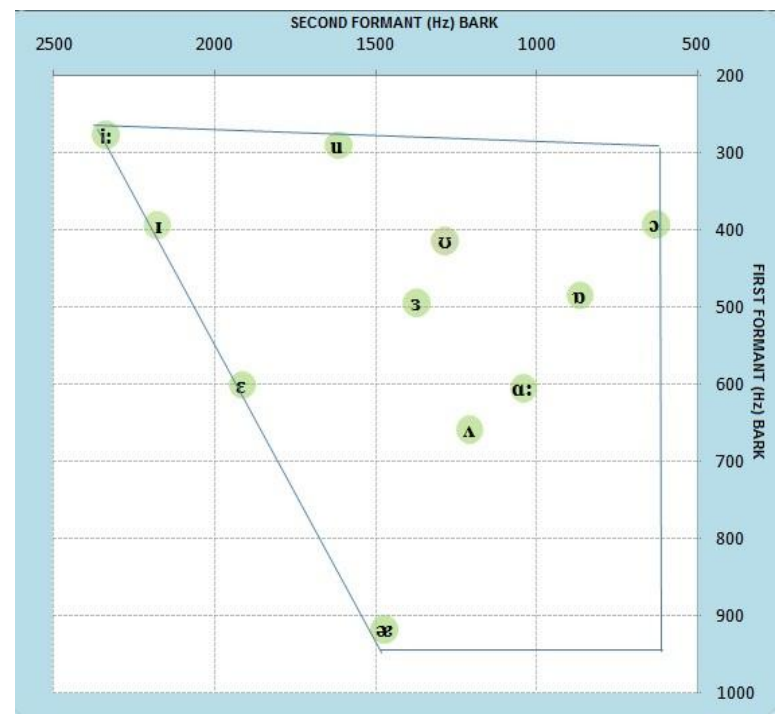

Figure 3. Vowel quadrilateral of British English native speakers

(Hawkins \& Midgley, 2005)

Figure 3 demonstrates the the vowel quality of British English native speakers. It can be clearly seen that each vowel is pronounced differently. The visual descrption aslo represents the mouth diagram of vowels. The up left is the lips and the buttom right is the back of the mouth.

We conducted the measurement of formant frequencies of ILE and L1 English pronouncing English vowels. The complete results of the acoustic measurement of L2 and L1 English vowels are shown in the following tables. Table 3 describes the result of F1 measurement in Hertz (Hz), Table 4 illustrates the ILE F2 and Table 5 represents the average of $F 1$ and $F 2$.

Table 2. ILE average of F1 and F2

\begin{tabular}{ccccc}
\hline $\begin{array}{c}\text { English } \\
\text { vowels }\end{array}$ & \multicolumn{2}{c}{ ILE } & \multicolumn{2}{c}{$\begin{array}{c}\text { English } \\
\text { L1 }\end{array}$} \\
\cline { 2 - 5 } & F1 (Hz) & F2 (Hz) & F1 (Hz) & F2 (Hz) \\
\hline & & 75 & & \\
\hline
\end{tabular}


Rudha Widagsa \& Ahmad Agung Yuwono Putro

Acoustic measurement on vowel production of English as a second language by Indonesian EFL Learners

\begin{tabular}{rrrrr}
\hline i: & 348,6 & 2088,6 & 276 & 2338 \\
\hline $\mathbf{I}$ & 361,4 & 2024,4 & 393 & 2174 \\
\hline $\mathbf{e}$ & 553,4 & 1824,6 & 600 & 1914 \\
\hline $\boldsymbol{x}$ & 586,8 & 1769,8 & 917 & 1473 \\
\hline $\mathbf{a}$ & 662,4 & 1315,6 & 604 & 1040 \\
\hline $\mathbf{p}$ & 449 & 1257 & 484 & 865 \\
\hline $\mathbf{D}$ & 534,4 & 1103,8 & 392 & 630 \\
\hline $\boldsymbol{U}$ & 374,6 & 1338,8 & 413 & 1285 \\
\hline $\mathbf{u}$ & 383,6 & 1240,6 & 289 & 1616 \\
\hline $\boldsymbol{\Lambda}$ & 618,6 & 1513,2 & 658 & 1208 \\
\hline $\mathbf{3}$ & 567,2 & 1450,2 & 494 & 1373 \\
\hline
\end{tabular}

Statistical analysis is intended to find out the significant differences between the productions of both groups language speakers. To test whether the F1 and F2 means were significantly different from each other, an independent $t$-test was conducted. The t-test results of the contrast of $\mathrm{F} 1$ and $\mathrm{F} 2$ between ILE and English native speakers is served in the following table.

Table 3. Independent t-test results comparing Indonesian and English native speakers on first formant (F1) and second formant (F2) frequencies of 11 English vowels produced in the $\mathrm{hVd} /$ contexts

\begin{tabular}{|c|c|c|c|c|c|}
\hline \multirow{2}{*}{$\begin{array}{c}\text { English } \\
\text { Vowel }\end{array}$} & \multicolumn{2}{|c|}{ F1 (Hz) } & \multirow[t]{2}{*}{$\mathbf{T}$} & \multirow[t]{2}{*}{ Df } & \multirow[t]{2}{*}{$\mathbf{p}$} \\
\hline & L1 & L2 & & & \\
\hline i: & 276 & 348,6 & $-18,297$ & 4 & 0 \\
\hline I & 393 & 361,4 & $-26,59$ & 4 & 0 \\
\hline e & 600 & 553,4 & $-37,012$ & 4 & 0 \\
\hline $\boldsymbol{x}$ & 917 & 586,8 & $-12,416$ & 4 & 0 \\
\hline $\mathbf{a}$ & 604 & 662,4 & $-18,819$ & 4 & 0 \\
\hline p & 484 & 449 & $-34,096$ & 4 & 0 \\
\hline o & 392 & 534,4 & $-10,55$ & 4 & 0 \\
\hline $\boldsymbol{\sigma}$ & 413 & 374,6 & $-10,297$ & 4 & 0,001 \\
\hline $\mathbf{u}$ & 289 & 383,6 & $-14,872$ & 4 & 0 \\
\hline$\Lambda$ & 658 & 618,6 & $-7,326$ & 4 & 0,002 \\
\hline 3 & 494 & 567,2 & $-24,562$ & 4 & 0 \\
\hline \multirow{2}{*}{$\begin{array}{c}\text { English } \\
\text { Vowel }\end{array}$} & \multicolumn{2}{|c|}{ F2 $(\mathrm{Hz})$} & $\mathbf{T}$ & Df & $\mathbf{p}$ \\
\hline & L1 & L2 & & & \\
\hline i: & 2338 & 2088,6 & 2,486 & 4 & 0,068 \\
\hline I & 2174 & 2024,4 & 4,306 & 4 & 0,013 \\
\hline e & 1914 & 1824,6 & 1,885 & 4 & 0,133 \\
\hline $\boldsymbol{P}$ & 1473 & 1769,8 & $-4,635$ & 4 & 0,01 \\
\hline $\mathbf{a}$ & 1040 & 1315,6 & $-6,933$ & 4 & 0,002 \\
\hline $\mathbf{p}$ & 865 & 1257 & $-8,425$ & 4 & 0,001 \\
\hline o & 630 & 1103,8 & $-6,215$ & 4 & 0,003 \\
\hline U & 1285 & 1338,8 & $-0,33$ & 4 & 0,758 \\
\hline $\mathbf{u}$ & 1616 & 1240,6 & 1,975 & 4 & 0,12 \\
\hline$\Lambda$ & 1208 & 1513,2 & $-3,592$ & 4 & 0,023 \\
\hline 3 & 1373 & 1450,2 & $-0,59$ & 4 & 0,587 \\
\hline
\end{tabular}

Independent $t$-test shows the distinctive result on $\mathrm{F} 1$ values, it can be seen that $\mathrm{F} 1$ values were significantly different from the production of $\mathrm{F} 1$ by native speakers. Surprisingly, there were only three vowels which were significantly different on $\mathrm{F} 2$ values $(/ \mathrm{a}, \mathrm{p}, \mathrm{o} /)$ which $/ \mathrm{a} /=p 0.002, / \mathrm{p} /=p$
$0,001, / \mathrm{J} /=p 0,03$. The rest of the vowels did not indicate the significant differences.

To compare the vowel space area of the Indonesian VSA and British English speakers in the $/ \mathrm{hVd}$ / context, the $\mathrm{F} 1$ and $\mathrm{F} 2$ values were inserted into a vowel quadrangle table (see Figure 4). The vowel quadrangle table refers to the place of articulation in the 
mouth and represents the position of the

tongue for each vowel.

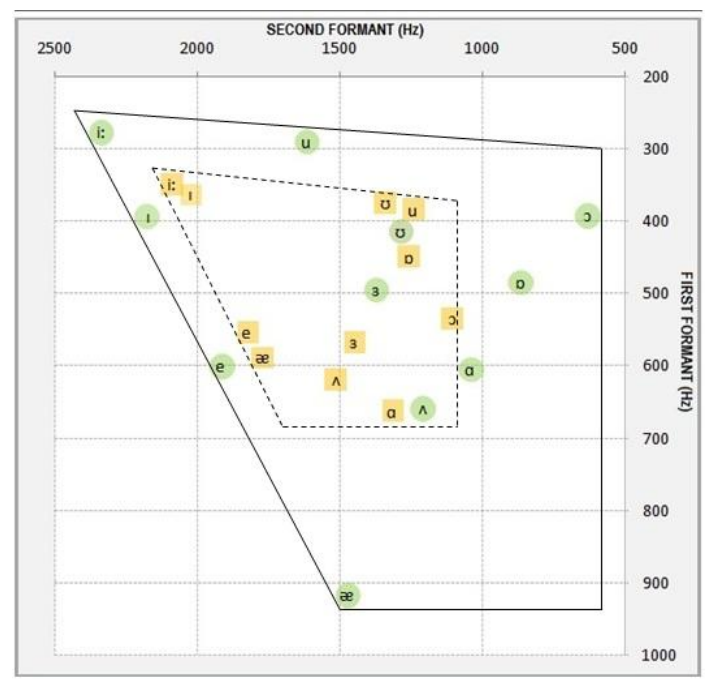

Figure 4. Quadrangle table (Barkscale)

Figure 4 illustrates the acoustic measurement of vowel formant frequencies and vowel space area of the English vowels produced by Indonesian learners of English which then compared with the native speakers of English. From the figure, it can be described that:

1. The native speaker of English had more spacious vowel space compared to Indonesian learners of English.

2. Indonesian learners of English were not able to distinguish the vowel /i:/ from the vowel /I/. They both were pronounced as simillar vowels and the formant frequencies were almost identical.

3. Indonesian learners of English produced the vowel /u/ which was close to the vowel $/ \mho /$.

4. The vowel $/ \mathfrak{x} /$ was pronounced slightly simillar to /e/. The production of $/ æ /$ was higher than the native speakers production.

5. The ILE production of vowel /a/ was identical to English L1 vowel $/ \Lambda /$.

6. The ILE produced the English vowels $/ \mathrm{p}$ and $\mathrm{u} / \mathrm{in}$ simillar way of producing the English vowel / $/$.

The first research question (1) would Indonesian learners of English show the same formant frequencies producing new vowels (/i:, æ, a:, o:, u:, $\Lambda$, 3:/)? PMH predicted that ILE would succeed to produce some English vowels where the vowels are similar in L1, conversely, ILE would be less successful in producing some English vowels which are different from L1 and the production of the English vowels would be identical to the nearest Indonesian vowels. In this experiment, ILE produced different $F 1$ values of /i:, æ, $a$, ๑:, u:, $\Lambda, 3: /$ from the corresponding F1 by L1 English. Surprisingly, the second formant did not demonstrate similar result in F2, only the three vowels /a, $\mathrm{b}, \mathrm{o} /$ which were significantly different. The vowels /a, $\mathrm{b}, \mathrm{s} /$ are almost identical to the Indonesian vowel system /a/. Thus, ILE tend to "attract" phonemes in English to standar exemplar phonemes of Indonesian.

ILE also showed the significant difference in pronouncing similar vowels $/ i$, e, $\mathrm{u} /$ based on the formant frequencies. The ILE $\mathrm{L} 2$ productions of $/ \mathrm{u}$ and $\mathrm{p} /$ are close to the English-L1/ /. Additionally, according to the visual investigation, the English-L1 vowel $/ \mathrm{N} /$ is pronounced as $/ \mathbf{a} /$. However, Indonesian learners of English show similarities to native English speakers in pronouncing the vowels $/ \mho /, / \mathrm{I} /$ and $/ \mathrm{e} /$. Futhermore, ILE were also unable to distinguish the long and short vowels /i:/ and /I/, the vowels / $/ /$ and $/ \mathrm{u} /$, what is more, the vowel /æ/ was also perceived as Indonesian /e/.

(2) The second research question is that to what extent that VSA English vowels produced by ILE are different from English- 
L1 VSA? Based on PMH, ILE would have different size of VSA from the corresponding VSA produced by English-L1. We predicted that Indonesian learners of English would have narrower VSA since they only have six vowels and would show a density of vowels in certain area. A part from this, based on PMH, Indonesian learners of English would pronounce inexistent English vowels close to Indonesian.

Based on the visual evidence, it can be seen that Indonesian learners of English has smaller VSA than native speakers. It also proves that ILE find difficulties in producing different vowels. Furthermore, there are some areas of English L1 which the vowels are denser than the other such as / $/ \mathrm{J} / \mathrm{I} / \mathrm{and} / \mathrm{e} /$. The evidences support the PMH theory that they will produce L2 where there is a similar sound in L1 in most cases; the learners would attract L2 phonemes to sample phonemes in L1.

The most difficult part in the vowel production by Indonesian learners of English is shown by the value of F1 rather than F2. It means that ILE were not able to perceive the English vowel height. Surprisingly, based on F2 values, Indonesian learners of English were able to perceive the degree of backness of English vowels.

\section{CONCLUSION}

As learning second language is heavily influenced by first language, the productions of English vowel by Indonesian native speakers were greatly influenced by the phonological system of Indonesian language. Indonesian learners of English were not aware of vowel height. However, in term of backness, there were only three vowels which were significantly different in the value of second formant.

This brings us to the conclusion that Indonesian learners of English have difficulties in producing English vowels which does not exist in Indonesian vowel system. The findings are consistent with the perceptual magnet hypothesis that Indonesian learners of English tended to produce approximations English phonemes based on Indonesian phonemes, they produced English vowels where there is similar sound in Indonesian.

This current research is only a preliminary study which still demands further research prior to acoustic features of English vowels produced by non-native speakers particularly Indonesian speakers. In this experiment, we only report data of Indonesian male respondents. Gender is known to be an important factor of phonetic variation. Gender and aged-related would also be interesting topic for future research. Hopefully, this research would shed light in English language teaching in Indonesia.

\section{REFERENCES}

Adisasmito-smith, N. (1999). Influence of javanese vowel patterning on Indonesian: An acoustic investigation. In 14th International Congress of Phonetic Sciences (ICPhS-14) (Vol. 14, pp. 11091112). Retrieved from https://www.internationalphoneticassociation.org/ icphs-proceedings/ICPhS1999/p14_1109.html.

Ball, M. J., \& Lowry, O. M. (2001). Methods in clinical phonetics. Philadelphia: Whurr Publishers.

Baker, W., \& Trofimovich, P. (2005). Interaction of native- and second-language vowel system(s) in early and late bilinguals. Language and Speech, 48(1), 1-27. Retrieved from https://doi.org/10.1177/00238309050480010101.

Boersma, P., \& Weenink, D. (2013). Praat: Doing phonetics by computer [Computer program] Version 5.3.51, retrieved 5 July 2013 from htt[://www.praat.org/.

Clynes, A., \& Deterding, D. (2011). Standard Malay (Brunei). Journal of the International Phonetic Association, 41(2), 259-268. Retrieved from https://doi.org/10.1017/S002510031100017X.

Dardjowidjojo, S. (2009). English phonetics and phonology for Indonesians. Jakarta: Yayasan Obor Indonesia.

Ferragne, E., \& Pellegrino, F. (2010). Formant frequencies of vowels in 13 accents of the British Isles. Journal of the International Phonetic Association, 40. Retrieved from https://doi.org/10.1017/S0025100309990247.

Finegan, E., Besnier, N,, Blair, D., \& Collinsm P. (1992). Language: Its structure and use. Marrickville: Hardcourt Brace Jovanovich Limited.

Flege, J. E. (1999). Age of learning and second language speech. In D. Birdsong (ed.) Second Language Acquisition and the Critical Period Hypothesis. NY: Lawrence Erlbaum Publishers, pp. 101-131.

Flege, J. E., Schirru, C., \& Mackay, I. R. A. (2003). Interaction between the native and second language phonetic subsystems. Speech 
ENGLISH REVIEW: Journal of English Education

Volume 6, Issue 1, December 2017

Communication, 40, 467-491. https://doi.org/10.1016/S0167-6393(02)00128-0.

Halim, A. (1974). Intonation in relation to syntax in bahasa Indonesia. Jakarta: Djambatan.

Hawkins, S., \& Midgley, J. (2005). Formant frequencies of RP monophthongs in four age groups of speakers. Journal of the International Phonetic Association, 35(35), 183-199. Retrieved from https://doi.org/10.1017/S0025100305002124.

Hunter, G., \& Kebede, H. (2012). Formant frequencies of British English vowels produced by native speakers of Farsi. Proceedings of the Accoustics 2012 Nantes Cinference.

Jones, D. (1957). An outline of English phonetics. Cambridge: W. Heffer \& Son Ltd.

Ladefoged, P., \& Johnson, K. (2001). Course in phonetics $\left(6^{\text {th }}\right.$ ed.).. Boston: Wadsworth.

Lado, R. (1957). Linguistics across cultures. Ann Arbor: The University of Michigan Press.

Marsono. (2008). Fonetik. Yogyakarta: Gadjah Mada University Press.

McAllister, R., Flege, J. E., \& Piske, T. (2002). The influence of L1 on the acquisition of Swedish quantity by native speakers of Spanish, English and Estonian. Journal of Phonetics, 30(2), 229258. Retrieved from https://doi.org/10.1006/jpho.2002.0174.

Iverson, P., \& Kuhl, P. (1995). Mapping the perceptual magnet effect for speech using signal detection theory and multidimensional scaling. Journal of the Acoustical Society of America, 97(1), 553562.
p-ISSN 2301-7554, e-ISSN 2541-3643

https://journal.uniku.ac.id/index.php/ERJEE

Perwitasari, A., Klamer, M., \& Schiller, N. O. (2016). Formant frequencies and vowel space area in Javanese and Sundanese English language learners. 3L: The Southeast Asian Journal of English Language Studies, 22(3), 141-152. Retrieved from http://ejournals.ukm.my/31/article/view/14498.

Peterson, G. E., \& Barney, H. L. (1952). Control methods used in a study of the vowels. Journal of the Acoustical Society of America, 24, 175-184.

Poedjosoedarmo, S. (1982). Javanese influence on Indonesian. Canberra: Department of Linguistic, Research School of Pasific Studies, The Australian National University (Pasific Linguistics, Series D, no. 38; Materials in Languages of Indonesia, 7).

Poedjosoedarmo, G. (1996). Variation and change in the sound systems of Brunei dialects of Malay. In Martin et al. (eds.), 37-42.

Pillai, S., \& Delavari, H. (2012). The production of English monophthong vowels by Iranian EFL learners. Poznań Studies in Contemporary Linguistics, 48(3), 495-518. Retrieved from https://doi.org/10.1515/psicl.

Sandoval, S., Berisha, V., Utianski, R. L., Liss, J. M., \& Spanias, A. (2013). Automatic assessment of vowel space area. The Journal of the Acoustical Spciety of America, 134(5), 14-17. Retrieved from https://doi.org/10.1121/1.4826150.

Zanten, E. V., \& Goedemans, R. (2009). Prominence in Indonesian strasses, phrases, and boundaries. Wacana: Jurnal Ilmu Pengetahuan Budaya, 11(2), 197-225. 
Rudha Widagsa \& Ahmad Agung Yuwono Putro

Acoustic measurement on vowel production of English as a second language by Indonesian EFL Learners 